Radosław Pawelec

(Uniwersytet Warszawski,

e-mail: r.pawelec@epoczta.pl)

ORCID 0000-0003-4739-6471

\title{
CZY JAN KOCHANOWSKI MIAL KOGOŚ LUB COŚ W NIENAWIŚCI? UŻYCIA SEÓW Z GNIAZDA <NIENAWIŚĆ> W TEKSTACH AUTORA TRENÓW NA TLE ICH ZNACZEŃ W XV I XVI WIEKU
}

O człowieku zasługującym na zbawienie, na „zażywanie wiecznego wesela świętego pałacu Boga”, tak mówi Jan Kochanowski w Psalmie 15:

1) Człowiek niewinny, człowiek uprzejmego

Serca, który sprawiedliwość miłuje,

Który nie mówi słowa fałszywego (...),

Ma niepobożne ludzi w nienawiści (...) [Kochanowski 1982, 108]

Autor fraszki Na lipe znał słowa nienawiść i nienawidzić i posługiwał się nimi. Czy znaczy to, że równie znajome było mu uczucie nienawiści $\mathrm{w}$ dzisiejszym rozumieniu, czy takim jego znaczeniem powinniśmy się posłużyć, odczytując powyższy cytat? Zadajmy też drugie, nie mniej ważne pytanie. Przytoczony kontekst dotyczy sfery stosunków międzyludzkich, ale mających ścisły zwiazek $z$ religia. Czy poeta odnosił te słowa także do relacji o charakterze ekonomicznym, politycznym, wreszcie motywowanym codziennymi problemami międzyludzkimi?

Odpowiedź na pierwsze pytanie jest złożona, w pewnym sensie też zaskakująca. Odpowiedź na pytanie drugie, zwłaszcza jeśli połączyć je $z$ refleksja nad dalszym rozwojem semantycznym słowa, odsłania groźna prawdę o zmianach $\mathrm{w}$ stosunkach między ludźmi i narodami, rozpoczętych w złotym wieku Polski, a nasilających się w kolejnych stuleciach.

Obie kwestie sa istotne dla rozwoju języka i kultury, obie wymagaja także spojrzenia szerszego: na rozwój semantyczny słów w dobie staropolskiej i XVI wieku. Dopiero bowiem na tym tle wychodzą na jaw ważne dla historii języka zależności. 


\section{OD JAKUBA NIENAWIDZĄCEGO LEI DO OPATA NAWIDZĄCEGO JAGIENKE}

Nienawiść to rzeczownik abstrakcyjny, swą budową słowotwórczą przypominajacy bardzo wiele nazw utworzonych w najstarszej dobie naszego języka i w XVI wieku, np. wolność, miłość, sprawiedliwość. Utworzono go od czasownika nienawidzić / nienawidzieć, logicznie więc od tego słowa należy zacząć poszukiwania semantyczne. Wiesław Boryś w Słowniku etymologicznym języka polskiego wskazuje, że nienawidzić to zaprzeczona forma czasownika nawidzić, jak zauważa, oba te słowa istniały w języku staropolskim, a wywodzą się od prasłowiańskich *nenavidèti, *navidèti. To ostatnie jest połączeniem przedrostka na- $i$ *vidèti; zdaniem etymologa psł. *navidèti oznaczało 'widywać się, odwiedzać, żyć w zgodzie, lubić, miłować kogoś', a (na odwrót, choć nie we wszystkich aspektach znaczenia) *nenavidèti - 'nie chcieć patrzeć na kogoś, nie chcieć kogoś widzieć, odczuwać wrogość do kogoś' [por. Boryś 2005].

Istnienie tych słów w polszczyźnie $\mathrm{w}$ dobie staropolskiej jest dobrze udokumentowane. Studiujac zgromadzone w Słowniku staropolskim [Sstp] przykłady, możemy również sądzić, że były to słowa (relatywnie) częste, $\mathrm{w}$ miarę rozbudowane jest też już wówczas gniazdo słowotwórcze $<$ nienawiści> (prócz rzeczownika i czasownika należą do niego leksemy nienawistny, nienawistność, maja one wszakże niewiele poświadczeń). Zdaniem leksykografów najwięcej użyć czasownika odpowiada znaczeniu zbliżonemu do współczesnego 'odczuwać silną wrogość połączona ze wstrętem i złościa, odisse', na drugim miejscu jest znaczenie zwiazane $z$ etymologia słowa, pojedyncze cytaty sa przypisane do znaczeń 'prześladować' i 'zazdrościć.

Analizując cytaty, można dojść do wniosku, że takie przyporządkowanie zostało dokonane głównie ze względu na odpowiedniki wyrazu w oryginalnym tekście łacińskim, który podlegał tłumaczeniu, nie bez wpływu były także współczesne użycia wyrazu. Gdyby kierować się treścią odpowiednich (zwłaszcza większych) fragmentów, należałoby nieco zmienić te proporcje (na niekorzyść znaczenia pierwszego), być może też nieco zmienić definicje Słownika (złagodzić je mianowicie). Przyjrzyjmy się dokładniej jednemu typowi takich użyć, dobrze ukazujacemu problem.

Drugie, najbliższe etymologii znaczenie czasownika nienawidzić to 'lekceważyć, odczuwać niechęć, pogardę, despicere, contemnere'. Posługując się nim, powinniśmy zdaniem słownikarzy eksplikować znaczenie słowa w cytacie:

2) A widząc Bóg, iż nienawidził (sc. Jakob) starszej (quod despiceret Liam)..., otworzył Bóg żywot jej [BZ Gen 29, 31]

By wyjaśnić, o co chodzi, trzeba przypomnieć dość skomplikowaną historię małżeńską Jakuba $z$ Księgi Rodzaju. Otóż służył on u Labana, starszego i zamożnego, a przy tym mającego dwie córki. Lea - starsza 
z nich - miała „czułe oczy”, Rachela - młodsza - „piękna postać i miłą powierzchowność" [tak w Biblii Tysiaclecia]. Jakubowi bardziej podobała się Rachela, ją też pokochał pierwszą miłością i ją obiecał mu za siedem lat wiernej służby Laban. Gdy jednak przyszło do ożenku, ojciec zmienił zdanie, uznał, że w pierwszej kolejności może wydać za mąż zgodnie ze zwyczajem tylko córkę starszą. Za młodszą zażądał kolejnych siedmiu lat służby. Jakub poślubił tedy Leę, ale służył kolejnych lat siedem, aż wreszcie otrzymał również młodszą córkę. Kochał ją bardziej, bardziej mu się podobała i wyraźnie ja preferował, jak możemy to po ludzku rozumieć - z krzywdą swej pierwszej żony. To „ludzkie rozumienie" najwyraźniej było bliskie też Bogu, który sprawił, że Lea powiła syna (a następnie jeszcze wielu innych), Rachela zaś (przynajmniej czasowo) była bezpłodna. Jest to tylko początek długiej historii rodzinno-majatkowej, której nie ma potrzeby tu opowiadać. Ważne jest co innego. Otóż słowo nienawidził znaczy w tym kontekście po prostu tyle, że Jakubowi Lea się niezbyt podobała. O jakiejkolwiek wrogości czy złych uczuciach nie może być mowy, zbyt mocne byłoby nawet powiedzenie, że wcale mu się nie podobała, przecież współżył $z$ nią i mieli wielu synów.

Kontekstów, w których nienawidzić odnosi się do stosunków międzyludzkich, jest wśród cytatów zgromadzonych w Słowniku staropolskim wiele. Co najmniej w stosunku do części z nich można dokonać podobnych interpretacji, pokazujac, że uczucie, które określaja, mieści się gdzieś na skali między miłościa, lubieniem, akceptacja a niechęcia, odrzuceniem i nienawiścia w dzisiejszym sensie. Tendencję do upraszczania tego stanu rzeczy i odczytywania ich przez pryzmat współczesnych znaczeń wzmacnia to, że już w XIV wieku jest sporo użyć bliskich drugiego końca skali, szczególnie w kontekstach religijnych (np. „jiż miłuje gospodzina, nienawidzi złego" - można domniemywać, że przy takim rozróżnieniu całkowicie spolaryzowane jest natężenie uczuć).

O tym jednak, że zasadniczo w analizie rozwoju znaczeniowego tych słów skalowanie, gradualne określanie wyrażanego przez nie wartościowania jest zasadne, przekonuje ich nieliniowy rozwój w dalszym okresie (por. s. 95, 96), a także specyfika znaczeniowa czasownika w formie niezaprzeczonej, zauważona przez Henryka Sienkiewicza i wykorzystana w celach archaizacyjnych. W Krzyżakach wielokrotnie jest mowa o tym, że ktoś kogoś nawidzi. Np. opat bardzo nawidzi Jagienkę, o czym Zych ze Zgorzelic z dumą mówi Maćkowi:

3) - A jakże. Zajeżdżał [opat]. Pięciu nowych chłopów z żonami na karczunkach osadził. I u nas, w Zgorzelicach, też bywał, bo jako wiecie, on mi krzcił Jagienkę, która zawsze bardzo nawidzi i córuchną ją zowie [Sienkiewicz 2006, 106]

Dla opata Jagienka jest jak jego własne dziecko. Nawidzenie w powieści nie ogranicza się do uczuć rodzicielskich, lecz także choćby do relacji między Jagienką a Zbyszkiem. Mowa o tym również, że Władysław Jagiełło nawidzi księżnę Aleksandrę, będącą wszak jego siostrą. Trudno dziś wnikać w tajniki 
królewskiego serca przed sześciuset laty, ale można się domyślać, że chodziło o poufały i laskawy stosunek, płynący z poczucia bliskości rodzinnej.

Intuicję językowa pisarza potwierdza materiał historyczny. Do naszych czasów dochował się wprawdzie tylko jeden cytat $z$ czasownikiem nawidzić, jednak jest on wyrazisty: w Rozmyślaniu przemyskim mowa o tym, że „dziewkę nawidzą i czynia ją matką", co odnosi się do zamiarów Stwórcy wobec Marii. Eksplikacja tego znaczenia to w Słowniku kochać, miłować, mieć w kimś upodobanie, amare, diligere'; w kategoriach sienkiewiczowskich można byłoby to porównać do uczuć królewskich wobec wybranej osoby.

\section{BĘDZIECIE W NIENAWIŚCI U WSZYSTKICH $Z$ POWODU MEGO IMIENIA [MT 10, 22]}

Patrząc na linię rozwoju semantycznego słów $z$ gniazda <nienawiść> $z$ dzisiejszej perspektywy, ex post, powiemy, że zmierza ona ku temu końcowi skali, na którym dominują silne wartości negatywne. Analizując wszakże jej przebieg w historii języka, widzimy, że jest ona meandryczna, przy tym nieco różna pod względem aksjologicznym w odniesieniu do poszczególnych leksemów $z$ gniazda, a także innych powiązanych semantycznie lub słowotwórczo wyrazów, które już wyszły $z$ użycia. ${ }^{1}$

Do takich wniosków prowadzi choćby porównanie znaczenia rzeczownika w dobie staropolskiej i analiza semantyczna opisywanych leksemów w XVI wieku. Podobnie jak w wypadku czasownika, w Słowniku staropolskim opisane sa cztery znaczenia nienawiści, niewielkie liczby cytatów przyporzadkowane sa do drugiego, trzeciego i czwartego, odpowiednio: 'lekceważenie, pogarda', 'prześladowanie' oraz 'zazdrość'. Najwięcej cytatów znajdziemy pod znaczeniem pierwszym 'uczucie silnej wrogości połączone ze wstrętem i złością, odium, invidia', nie sposób się przy tym oprzeć wrażeniu, że sa one wyrazistsze niż użycia czasownikowe. Odpowiadający użytemu w podtytule, cytowanemu za Biblia Tysiaclecia, fragment Ewangelii wg św. Mateusza brzmi w Rozmyślaniu przemyskim:

4) I synowie powstaną przeciw ojcom i będą umęczać aż do śmierci, i będziecie w nienawiści wszytkiemu ludu prze moje imię.

Inne przykłady to choćby: „A jeśli kto $z$ nienawiści człowieka goni (...), a on by od tego umarł, wróg mężobójstwa winien będzie”, „zamęczyliście mnie i wielką nienawiść uczyniliście”. Warto zwrócić uwagę, że konstruk-

$1 \mathrm{~W}$ dobie staropolskiej i średniopolskiej używany był też czasownik nienajrzeć oraz imiesłów nienajrzacy i rzeczownik nienajrzenie, znaczenie tych słów było synonimiczne do nienawidzić, choć w wielu cytatach można zauważyć silniejsze wartościowanie. Ciekawe było zróżnicowanie znaczeniowe wyrazów nienawistny / nienawisny (u S.B. Lindego także: nanawidny) - zależnie od kontekstu znaczyły one bowiem 'nienawiść ku drugim mający' lub 'którego drudzy nienawidza'. 
cja składniowa w ostatnim przykładzie wskazuje na to, że nienawiść mogła być rozumiana nie tylko jako uczucie, ale także jako czyn będący jego konsekwencją. W pierwszym zaś i podstawowym do dziś znaczeniu występowała często w konstrukcjach dziś już przestarzałych lub książkowych: być $w$ nienawiści, jak w cytacie (4) lub wpaść, upaść $w$ nienawiść (np. „Antypater upadł w wielka nienawiść ludu”).

Czy $z$ tego, że pod koniec średniowiecza znaczenie rzeczownika wydaje się bardziej nacechowane negatywnie niż użycia czasownikowe wynika, że w stuleciu ostatnich Jagiellonów ta degradacja ${ }^{2}$ się pogłębi i obejmie także inne części mowy? Otóż wcale nie. Ich semantykę można dość precyzyjnie odtworzyć, w materiałach Słownika polszczyzny XVI wieku (SXVI) mamy bowiem prawie 600 cytatów ze słowem nienawiść, ponad 200 użyć czasownika nienawidzieć (również w formie zwrotnej: nienawidzieć się), a także pojedyncze użycia zaskakująco licznych derywatów odrzeczownikowych i form odczasownikowych: nienawisnie, nienawisny (35 cytatów), nienawistnik (9 cytatów); nienawidzenie, nienawidzacy (12 użyć, także $\mathrm{w}$ formie substantywizowanej), nienawidzony, nienawidzian.

Wszystkie, jakże liczne, użycia czasownika i rzeczownika (podobnie zreszta, jak i owych znacznie mniej licznych derywatów i form) są zaklasyfikowane do jednego tylko znaczenia, odpowiednio: 'bardzo nie lubić, odisse'; 'silna, trwała niechęć, odium'. Takie eksplikacje wyrażają wartościowanie słabsze niż dziś, słabsze też niż ich odpowiedniki w Sstp. Sa jednak adekwatne wobec materiału, o czym przekonujemy się, analizujacc cytaty. Oto przykłady użyć czasownika:

5) który nienawidzi łakomstwa/ długie będą dni jego [Leop Prov 28/16]

6) nienawidzieć a nieprzyjacielskie nacierać na tego/ który się zda jakoby zbłądził / jest rzecz człowieka srodze jadowitego [ModrzBaz 65]

7) córkę moją dałem mężowi temu za żonę / i nienawidzi jej [BudBip Deut 22/16]

8) Chceszli dobrym być odejm to od siebie czego w innym nienawidzisz [BielŻyw 77]

9) Tyranów (...) nie słowy tylko / ale uczynkiem / jako się godziło / nienawidział [Phil E2]

Słowo nienawidzieć odnoszone było zarówno do ludzi, jak i do rzeczy. Cytaty (5) i (8) dokumentuja ten drugi typ połączeń. Oczywiście trudno $\mathrm{w}$ nich mówić o wrogości czy też szczególnie intensywnym wartościowaniu, chodzi po prostu o nielubienie czegoś, niechęć do jakiejś cechy czy zachowania. Cytat (8) jest o tyle ciekawy, że ujmuje rzecz w sposób bliski współczesnym zaleceniom psychologicznym: nie negować czyjejś osobowości w całości, a jedynie określone cechy negatywne.

$\mathrm{W}$ większości cytatów czasownik nienawidzieć odnosi się jednak do ludzi, nie zaś ich cech, wyraża przy tym wartościowanie silne, ba! niekiedy chodzi nie tylko o uczucia, ale także o czyny. Mowa o tym w cytacie (6) i (9),

2 Terminu tego używamy w znaczeniu, w którym występuje w książce Danuty Buttler Rozwój semantyczny wyrazów polskich [w wielu miejscach, por. np. Buttler 1978, 133]. 
w tym ostatnim znajdujemy interesująca, dziś już niespotykaną konstrukcję składniowa: nienawidzić kogoś czymś (w tym wypadku: uczynkiem).

O tym, jakie znaczenie miało słowo wtedy, gdy wyrażało wartościowanie silne, pośrednio informują cytaty, w których jest przeciwstawiane umiłować, kochać i połączenia szeregowe, w których występuje obok uragać, prześladować, złość wyrzadzić. Nie zawsze jednak to, że ktoś kogoś nienawidzi oznaczało owo silne uczucie, niekiedy łączone $z$ takimi choćby działaniami jak wymienione w cytowanych szeregach. W cytacie (7) mowa o nienawidzeniu żony, można sądzić, że chodzi tu raczej o brak zainteresowania, może też o niechęć - podobnie jak w opisanym w punkcie 1 . kontekście biblijnym (por. s. 93).

Znaczenie leksemu nienawidzić w cytatach XVI-wiecznych jest szerokie, obejmuje całe spectrum uczuć, od nielubienia, niechęci, przez wiele stopni pośrednich, aż po silną wrogość połączona $z$ czynami polegającymi na wyrządzaniu komuś zła. Semantyka rzeczownika jest podobna, choć - tak jak w poprzedniej epoce - można uważać, że wartościowanie wyrażane w większości cytatów jest bardziej dobitne:

10) z drugimi by też koty drzeć / albo jakąś nienawiść wieść musiał [cum aliis simultatem vel inimicitias exerceat] [ModrzBaz 44v]

11) Zmianka tu jest o zdradzie Judaszowej nad Panem Chrystusem i o nienawiści żydowskiej przeciwkoż niemu [Leop PS 108 arg.]

12) Złotniki miałem w nienawiści (...) a zakon twój Panie miłowałem [WróbŻołt $118 / 113]$

13) przystapił chcac je zgodzić: Co się tako sromocicie / Nienawiść sobie czynicie [BierEz L4v]

14) $z$ wielkiego jadu i dostałej a rozmyślnej nienawiści [zelżył brata swego] [SkarKaz 313a]

W Elektronicznym słowniku łaciny średniowiecznej znaczenie inimicitia, które jest odpowiednikiem słowa nienawiść w cytacie (10), jest objaśniane jako 'nieprzyjaźń, wrogość, niechęć, niezgoda, nienawiść', do użyć w liczbie mnogiej odnosi się podobna eksplikacja 'wrogie uczucia, niesnaski, nieprzyjazne stosunki' [ESŁS]. Jest to zatem znaczenie szerokie; o tym, że wcale niekoniecznie w tym zdaniu chodzi o najsilniejsze uczucia negatywne, świadczyć może zestawienie $z$ darciem kotów, co dawniej miało sens dość podobny do dzisiejszego.

W kolejnych przykładach znajdujemy użycia intensywniejsze pod względem wartości. Przypisywana Żydom $z$ czasów biblijnych nienawiść do Jezusa miała groźny wymiar, w cytacie (12) nienawiść jest przeciwstawiana $z$ kolei miłości. Takich przeciwstawień jest znacznie więcej, jako uczucie przeciwne do nienawiści wskazywane sa w nich także miłowanie, przyjaźń, chuć, sława. Sromocić kogoś, o czym mowa w cytacie (13), znaczyło 'hańbić', konstrukcja 'nienawiść czynić' jest przez autora hasła w SXVI tłumaczona jako 'wzbudzać w sobie nawzajem nienawiść'.

Niewatpliwie najsilniejsza ocena jest ewokowana przez słowo nienawiść w ostatnim $z$ przywołanych cytatów. Pochodzi on z Kazań sejmo- 
wych Piotra Skargi, w których kaznodzieja naucza m.in., że dla Jezusa gniew ludzki ma trzy stopnie. Pierwszy: „tak mały, że się żadnym słówkiem nie wydaje”. Drugi: „który już się słowem bez zelżywości bliźniego ukazuje”. Trzeci: „który złe, zelżywe słowo na bliźniego miece”. Ocena tego trzeciego jest najsurowsza $z$ możliwych, oto większy fragment tekstu:

15) kto $z$ wielkiego jadu i dostałej a rozmyślnej nienawiści, ${ }^{3}$ która jest mężobójstwu równa, jako Jan ś. mówi, iżby go rad zabił, i na sercu to już uczynił, gdy w tem wyrzecze zelżywe słowo na bliźniego, już go na sercu zabił; i przeto karanie takie zasługuje [Skarga, Kazania, 184]

W XVI wieku nienawiść występuje już w dzisiejszym, silnym znaczeniu oceniajacym, słowo to jednak może wyrażać także wartościowania nieco słabsze, odnosi się przy tym - podobnie jak czasownik - do szerokiej gamy uczuć, postaw i zachowań ludzkich. Dobrze świadczy o tym bardzo szeroka jego łączliwość i wielka różnorodność konstrukcji składniowych leksemu. Można było powiedzieć: nienawiść kogo, czego, do kogo, do czego, ku komu, przeciw komu, czemu, przestawać $w$ nienawiści; nienawiść cierpieć, czynić, kłaść, mieć. Możliwe połączenia tylko tego ostatniego zwrotu to m.in. (mieć $w$ nienawiści) marna bestyja, bezbożność przeklęta, bliźniego, boża miłość, brata, chwałę nieprzyjacielska itd. - wyliczenie wszystkiego zajęłoby wiele stron.

\section{CZŁOWIEK NIEWINNY (...) MA NIEPOBOŻNE LUDZI W NIENAWIŚCI (...)}

Jak na tym tle należy rozumieć użycie słowa w przytoczonym we wstępie fragmencie Psalmu 15? Jeżeli cytat ten odczytamy przez pryzmat współczesnego znaczenia słowa, otrzymamy konstrukcję o charakterze oksymoronicznym. Przytoczmy pełny kontekst, by ukazać sprzeczność:

16) Kto będzie w Twoim mieszkaniu przebywał?

Kto będzie Twego pałacu świętego,

Wieczny mój Boże, wesela zażywał?

Człowiek niewinny, człowiek uprzejmego

Serca, który sprawiedliwość miłuje,

Który nie mówi słowa fałszywego,

Który bliźniego swego nie szacuje,

Nie szuka z cudzą szkoda swej korzyści,

Przeciw obmowcom sąsiada ratuje,

Ma niepobożne ludzi w nienawiści,

Dobrym, gdzie może, pomocy dodawa,

3 Szereg ,jad i nienawiść” z kazania P. Skargi przetrwał do naszych czasów. W „Dzienniku Łódzkim” 19.01.2019 r. ukazał się obszerny artykuł Marcina Dardy, zatytułowany Atmosfera jadu i nienawiści miała wpływ na zabójce Adamowicza. 
A co przyrzecze, by naciężej - ziści;

Pieniędzy w lichwę nikomu nie dawa,

Nie bierze darów przeciw niewinnemu:

Kto sie tak rządzi, kto przy tym zostawa,

Śmiele niech ufa pokojowi swemu [Kochanowski 1982, 44]

Tekst jest odpowiedzia na pytanie: kto zasługuje na zbawienie? „Kto będzie w Twoim mieszkaniu przebywał?”. Przedstawia osobę prawego, dobrego człowieka, pełnego zalet charakteru i bojaźni bożej. Jest niewinny, uprzejmego serca, miłuje sprawiedliwość, nie kłamie itd. Doprawdy trudno założyć, że wśród tych wszystkich cnót Mistrz z Czarnolasu wymienia jednym tchem hodowanie w sercu wrogości wobec kogokolwiek, połączonej z chęcią czynienia zła. Owszem, może chodzić o nielubienie, brak akceptacji czy nawet brzydzenie się, jednak wprowadzenie tu współczesnego znaczenia stwarza wyraźny dysonans.

Nie jest to wszakże jedyne znaczenie wyrazu w poezji Jana Kochanowskiego. Wyraźnie inne jest np. użycie w Psalmie 36. W tekście mowa o boskiej dobroci, zarazem jednak w zakończeniu - także o boskiej pomście, która dosięga hardego i niepobożnego człowieka. Podobnie jak poprzednio przytaczamy cały tekst:

17) Żywot niepobożnego za świadka mi stoi, Że on o Bogu nie wie ani się Go boi,

Więc jeszcze w swychże złościach sobie pochlebuje,

Za co bożą i ludzką nienawiść zyskuje.

Jego słowa szczera złość, szczery kłam i zdrada,

Nie ma tam nigdy miejsca żadna zdrowa rada.

W nocy myśli, w jakiej dzień strawić wszeteczności,

Cnotę wzgardził umyślnie - przyjacielem złości.

O Panie, dobroć Twoja do nieba przestała,

Prawda obłoków sięga, góry przerównała

Sprawiedliwość, a sądów i Twojej mądrości

Taż jest miara, która jest morskich głębokości.

Z Twych rak człowiek, $z$ Twych rak zwierz maja zdrowie swoje;

Nieprzepłacone, Panie, miłosierdzie Twoje;

Jako ptak liche dziatki skrzydły swymi kryje,

Tak człowiek pod zasłoną łaski Twojej żyje.

Hojnością domu Twego będziem nasyceni

I strumieniem rozkoszy Twoich napojeni;

U Ciebie zdrój żywota, Ty nasze ciemności

Rozświecisz, a wnet ujźrzem dzień prawej światłości.

Okryj, Panie, łaską swą tych, którzy Cię znaja,

Którzy cnoty w każdej swej sprawie przestrzegaja;

Niechaj mię hardy człowiek nie depce nogami,

Niechaj mię niepobożny nie tyka rękami! 
Aczci tak długo będą na dobrych przewodzić

I niewinne wszelakim obyczajem szkodzić,

Że przecię czasu swego przypłaca swych złości

A nie ujdą Twej pomsty, Panie, i srogości [Kochanowski 1982, 108]

Tym razem, jak się wydaje, mamy do czynienia $z$ silnym znaczeniem wartościującym słowa: człowieka niepobożnego, który odwrócił się od Boga i szkodzi bliźnim, otacza wrogość innych ludzi, jego czyny i postawa zasługuja na boską srogość i pomstę.

Te i pozostałe użycia badanych słów w tekstach Jana Kochanowskiego potwierdzaja wnioski sformułowane w odniesieniu do całości użyć szesnastowiecznych wyrazów, w utworach poety widzimy to samo zróżnicowanie znaczeniowe słowa nienawiść, które istnieje w materiałach dotyczących polszczyzny owego stulecia. Całkiem udatnie odzwierciedlaja to definicje Słownika polszczyzny Jana Kochanowskiego (SPJK), znaczenie rzeczownika jest w nich eksplikowane jako 'silna niechęć, wrogość w stosunku do kogoś, wstręt', a czasownika 'nie lubić kogoś bardzo, odczuwać silną niechęć do kogoś, nie akceptować czyjegoś postępowania'.

Czy na tej podstawie można udzielić odpowiedzi na któreś ze sformułowanych we wstępie pytań? Wydaje się, że wciąż nie: uwzględnić trzeba mianowicie jeszcze jeden bardzo istotny czynnik, o którym dotychczas nie było mowy. Chodzi o umiejscowienie cytatów ze słowami nienawiść i nienawidzić w twórczości autora Zgody. Tych pierwszych jest dziewięć, cytat $z$ czasownikiem jest jeden. Wszystkie one, prócz jednego użycia rzeczownika, pochodza z Psałterza Dawidowego! A ów jeden $z$ dość wczesnego utworu pt. O śmierci Jana Tarnowskiego, Kasztelana Tarnowskiego, do syna jego, Jana Krisztofa [1561]. W dojrzałej twórczości poety, poza tłumaczeniami ze starotestamentowej Księgi Psalmów, słowa te w ogóle nie są używane. Jest to bardzo wyrazista różnica między jego językiem a językiem ogólnym, w którym nie dość, że mamy bardzo wiele użyć, ale też występują one w przeróżnych tekstach, mają różnorodne odniesienia, składnię, rozbudowana łączliwość, o czym pisaliśmy w poprzednim punkcie. Czym wytłumaczyć tę rozbieżność?

Pierwsze, co trzeba wziąc pod uwagę, to ogólny charakter tekstów autora Trenów. W znacznej większości $z$ nich - ze względu na tematykę, treść przekazu i czynniki genologiczne - nie ma miejsca na mówienie o takich uczuciach jak nienawiść. Dotyczy to na pewno fraszek, pieśni czy trenów. To jednak sprawy nie rozwiazuje, gdyż np. w Odprawie posłów greckich jest dość miejsc, w których można byłoby wyrazy odnoszące się do tego pojęcia umieścić. Mowa tam wszak o „obelżeniu i krzywdzie znacznej”, której nie chcieli cierpieć Grekowie, Helena określa Aleksandra jako „bezecnego”, który jak „drapieżny wilk rozbija stado”. Przypomnijmy też, jak Aleksander podburza w radzie gniew przeciw Grekom:

18) (...) im każdy, a oni nie winni nikomu

Sprawiedliwości czynić. (...)

Nie tuszęć ja, żebyś ty, ojcze mój łaskawy, 
Nie pomniał jeszcze krzywdy i szkód starodawnych,

Któreś wzią od tych panów i to państwo sławne.

Jeszczeć mury leżą na ziemi powalone

I pola do tej doby pustyniami stoja,

Znaki miecza greckiego i okrutnej ręki [Kochanowski 1989, 595]

Dalej mowa jest o ludziach wziętych w niewolę i przetrzymywanych, lud na przypomnienie tego wszystkiego reaguje wzburzeniem. Wywiazuje się żarliwa dyskusja, w której mowa o sprawiedliwości i niesprawiedliwości, krzywdzie i poście, co kończy, jak wiadomo, decyzja o nieoddawaniu Heleny. Podsumowaniem ze strony posłów greckich jest słynny monolog Ulissesa, zaczynający się od słów „O nierządne królestwo i zginienia bliskie...", pełen mocnych wyrazów, jak wszeteczny, łotrowski, wrzód.

Słowa nienawiść i nienawidzić nie padaja jednak! - ani w tym fragmencie, ani w całej tragedii, ani też w ogóle w twórczości poety z Czarnolasu, poza tłumaczeniami psalmów i wymienionym wierszem. Trudno uznać to za przypadek, jest to niewattpliwie świadoma decyzja autorska, rodzaj ograniczenia, jakie Jan Kochanowski nałożył na swój język.

Jednak dlaczego? Przecież znał dobrze wieloznaczność nienawiści, wszak sam ją do pewnego stopnia wykorzystywał. Ogromna liczba cytatów ze słowami $z$ tego gniazda wskazuje na to, że słyszał je bardzo często, wypowiadane w różnych sytuacjach, czytał je w tekstach różnego typu, ich użycie nie było obłożone żadnym tabu.

Wszelkie odpowiedzi na to pytanie po przeszło czterech wiekach moga być tylko przypuszczeniami. To, które wydaje się najbardziej prawdopodobne, ma związek $z$ dalszym rozwojem semantycznym owych słów.

\section{KRĄG ZATOCZONY MIECZEM MŚCIWEJ NIENAWIŚCI - ZAKOŃCZENIE}

Jak powiedzieliśmy, w SPJK nienawiść jest eksplikowana określeniami bliskimi znaczeniowo, ale niejednoznacznymi, zwłaszcza pod względem wartości: 'silna niechęć, wrogość w stosunku do kogoś, wstręt', w SXVI wydobyty jest tylko pierwszy element 'silna, trwała niechęć'. Definicja w słowniku obejmującym materiał kolejnych dwóch wieków jest znacznie bardziej dosadna: 'uczucie trwałej wrogości, gniewu, złości' [Elektroniczny słownik języka polskiego XVII i XVIII wieku]. W Słowniku jezyka polskiego Samuela Bogumiła Lindego znajdujemy definicję dwudzielną: a) 'zawiść, gniew długo chowany'; b) 'zazdrość' [SL], oczywiście należy pamiętać, że ten słownik obejmuje również materiały XVI-wieczne.

Natomiast w Słowniku języka Adama Mickiewicza słowo nienawiść pozostawiono bez definicji, podobnie zreszta jak czasownik, co wskazuje na to, że zdaniem redaktorów wyrazy te występuja we współczesnym sensie. Adekwatne w tym wypadku będą definicje ze Słownika języka polskiego Witolda Doroszewskiego, nienawidzić jest w nim definiowane 'czuć do kogoś 
nienawiść, odrazę, wstręt, nie cierpieć, nie znosić', nienawiść zaś - 'uczucie silnej wrogości, niechęci do kogo (czego)'. Znaczenia obu słów ilustrowane sa wyrazistymi cytatami, m.in. z tekstów Adama Mickiewicza i Henryka Sienkiewicza, ich zestaw otwiera fragment sonetu Leopolda Staffa Światy:

19) Gdyby świat widział jeno cała swoja sławę

W dziełach rak waszych, wojny synowie nieczyści,

Którzy hańbicie piękno wawrzynowych liści,

Krwawymi dłońmi kładąc je na czoło krwawe;

Gdyby za cała musiał wystarczyć nam jawę

Przesycony chuciami zysku i korzyści

Krag zatoczony mieczem mściwej nienawiści:

Jakież by życie było nędzne i plugawe! [Staff 1955, 32]

Linia rozwoju semantycznego słów $z$ gniazda <nienawiść> po XVI wieku wydaje się prosta: zmierza ona do ujednoznacznienia aksjologicznego, połączonego $z$ degradacja i usytuowaniem na krańcu skali wartości negatywnych. W efekcie w ostatnich dwu stuleciach te leksemy zaliczają się do najmocniejszych słów oceniających w języku polskim. Ponieważ nie można zakładać, że ta zmiana językowa była oderwana od biegu dziejów i rzeczywistości, musimy przyjąć, że takie wyrazy były najwyraźniej Polakom potrzebne, by opisać stan spraw narodowych i społecznych. Przekonuje o tym choćby sama siła, niebywała ostrość XIX- i XX-wiecznych kontekstów, takich jak choćby przywołany wyżej z dzieł autora Snów o potędze.

Wróćmy do Jana Kochanowskiego. Być może to ostrze złej wartości w słowie kiełkowało już w XVI wieku i poeta $z$ Czarnolasu dostrzegł owa niebezpieczna tendencję? Dalszy rozwój języka, a także duża już ówcześnie liczba „ostrych” użyć słowa, wskazują nie tylko na to, że istniała, ale też że mogła być zauważalna. Pisarz nie mógł zmienić rozwoju języka ogólnego, ale mógł kształtować własny język. ${ }^{4}$ Może też po trosze - własny świat, a przynajmniej - świat odbity w swych utworach. Nie przywoływał nienawiści, mówiąc o stosunkach między ludźmi, by „krag zatoczony jej mściwym mieczem" nie zburzył humanistycznej, renesansowej harmonii jego twórczości.

4 Można tu dodać istotna informację dotyczaca specyfiki językowo-aksjologicznej Psałterza Dawidowego. Charakterystyczne dla thumaczenia Jana Kochanowskiego jest mianowicie to, że operuje wieloma konstrukcjami zaprzeczonymi, często pojawiającymi się w przeciwstawieniach wartości. Np. w Psalmie 1, Szczęśliwy, który nie był miedzy złymi w radzie, pełniacy Pańskie przykazanie, podobien drzewu porzecznemu itp. jest przeciwstawiany grzesznym, co się ze zdrowej nauki naśmiewaja, złym, którzy Boga i wstydu nie maja, tego szczęścia, tej nigdy zapłaty nie maja, przed sądem musza być pohańbieni itp. Występowanie nazw antywartości $\mathrm{w}$ takich opozycjach $\mathrm{z}$ reguły jest skorelowane $z$ użyciem licznych negatywów. Nie przeczy to jednak wyżej sformułowanej hipotezie, lecz raczej ją wzmacnia: wszak tekst psalmów odnosi do innego porządku wartości niż codzienne stosunki międzyludzkie. 


\section{Bibliografia}

W. Boryś, 2005, Słownik etymologiczny języka polskiego, Kraków.

D. Buttler, 1978, Rozwój semantyczny wyrazów polskich, Warszawa.

W. Doroszewski (red.), 1958-1969, Słownik języka polskiego, Warszawa.

Elektroniczny słownik języka polskiego XVII i XVIII wieku, sxvii.pl, dostęp: maj 2019 r.

Elektroniczny słownik łaciny średniowiecznej w Polsce, sciprores.pl/elexicon, dostęp: maj 2019 r.

K. Górski, S. Hrabec (red.), 1962-1983, Słownik języka Adama Mickiewicza, t. 1-11, Wrocław [SMick].

J. Kochanowski, 1982, Dzieła wszystkie, część 1: Psałterz Dawidów, Wrocław.

J. Kochanowski, 1989, Dzieła polskie, Warszawa.

M. Kucała (red.), 1994-1998, Słownik polszczyzny Jana Kochanowskiego, t. 1-2, Kraków [SKoch].

S.B. Linde, 1807-1814, Słownik języka polskiego, t. 1-6, Warszawa (przedruk, Warszawa 1951).

M.R. Mayenowa (red.), 1966-2001, Słownik polszczyzny XVI wieku, t. 1-33, Wrocław-Warszawa-Kraków [SXVI].

H. Sienkiewicz, 2006, Krzyżacy, Kraków, s. 106.

L. Staff, 1955, Wiersze zebrane 4, Warszawa.

S. Urbańczyk (red.), 1953-2002, Słownik staropolski, t. 1-11, Wrocław-Warszawa-Kraków [SStp].

\section{Did Jan Kochanowski hate someone or something? Usages of words from the nest <nienawiśc > (hatred) in the texts by the author of Treny (Laments) against their meanings in the $15^{\text {th }}$ and $16^{\text {th }}$ century}

\section{Summary}

This paper presents an analysis of the usages of words from the nest $<$ nienawiść> (hatred) in the works by Jan Kochanowski against the semantic development of these words in Polish. Their original etymological meaning is related to seeing someone unwillingly, disliking someone. In the Old and Middle Polish periods, they were used fairly often, but the usages were different from the present ones: many of them had a less negative meaning than they do in Modern Polish. It was shaped after the $16^{\text {th }}$ century, yet the beginnings of the process are assumed to go back to the century of the last Jagiellons. The author formulates a hypothesis that Jan Kochanowski, who noticed the trend in the semantics of the words from the nest <nienawiść>, restricted their usage in his works only to the translations of the Old Testament psalms, consciously not referring them to the contemporary interpersonal relationships.

Keywords: history of language - lexicography - etymology - artistic language semantic evolution of lexical units - emotional markedness of vocabulary - nest $<$ nienawiść> (hatred). 